\title{
PENGEMBANGAN SUMBER DAN MEDIA PEMBELAJARAN IPS UNTUK MENINGKATKAN ECOLITERACY PESERTA DIDIK
}

\author{
Oleh: \\ Silvi Nur Afifah \& Lailatul Rofiah \\ Prodi Pendidikan IPS, Universitas Islam Raden Rahmat \\ Malang \\ Email: silvinurafifah1@gmail.com
}

\begin{abstract}
Abstrak
Penelitian ini memiliki tujuan untuk mengembangkan sumber dan media pembelajaran IPS dengan menghasilkan sebuah modul dan implementasi proses pembelajaran yang menjadi salah satu penggerak dalam meningkatkan ekoliterasi peserta didik dengan cara mendaur ulang kemasan produk konsumsi terutama dari kemasan botol plastik. Metode penelitian ini menggunakan model pengembangan (Research and Development) Borg dan Gall dengan subjek penelitian Mts Al-Hidayah Wajak, yang menghasilkan sebuah produk kreasi daur ulang dari sampah botol plastik yang mengadopsi dari materi Kewirausahaan. Modul didesain agar peserta didik bisa mempraktekkan daur ulang sampah yang kreatif dan inovatif, dampak sampah plastik yang tidak didaur ulang bagi masyarakat dan solusi untuk mengatasinya, yang kedua adalah macam-macam kreasi dan inovasi daur ulang sampah plastik yang terdiri dari dua puluh satu kreasi sampah botol plastik dan langkah-langkah dalam membuatnya, dan yang terahir adalah kisah-kisah inspiratif yang berasal dari pengusaha sampah plastik. Sumber dan media pembelajaran IPS yang berupa modul yang telah dikembangangkan telah di implementasikan dalam proses pembelajaran, proses pembelajaran berjalan sangat menyenangkan hal tersebut terlihat dari antusias peserta dalam mengikuti pembelajaran karena peserta terlibat langsung dalam proses pemanfaatan/mendaur ulang sampah botol plastik.
\end{abstract}

Kata Kunci:

Sumber Belajar IPS, Media Belajar IPS, Pembelajaran IPS, Ecoliteracy 


\section{Abstract}

This study aims to develop social studies learning resources and media by producing a module and implementing a learning process that becomes one of the driving forces in increasing the ecoliteration of students by recycling consumer product packaging, especially from plastic bottle packaging. This research method uses the development model (Research and Development) of Borg and Gall with the research subject of Mts Al-Hidayah Wajak, which produces a recycled creative product from plastic bottle waste that adopts entrepreneurship materials. The module is designed so that students can practice creative and innovative waste recycling, the impact of plastic waste that is not recycled for society and solutions to overcome it, the second is various kinds of plastic waste recycling creations and innovations consisting of twenty one waste creations plastic bottles and the steps in making them, and finally, inspiring stories from plastic waste entrepreneurs. Social studies learning resources and media in the form of modules that have been developed have been implemented in the learning process, the learning process is very pleasant, this can be seen from the enthusiasm of the participants in participating in the lesson because participants are directly involved in the process of utilizing and recycling plastic bottle waste.

\section{Key words: social studies learning source, social studies learning media, social studies learning, ecoliteracy}

\section{Pendahuluan}

Jumlah sampah atau limbah dari hari ke hari semakin tidak terbatas. Limbah kemasan makanan dan minuman menjadi salah satu penyumbang besarnya. Total jumlah sampah Indonesia di 2019 mencapai sekitar 68 juta ton atau 14 persen dari total sampah yang ada (Republika, 2019). Beasarnya jumlah sampah menimbulkan banyak kerugian terhadap lingkungan, salah satunya pencemaran. Tidak bisa di sangkal bahwa kasus lingkungan hidup yang salah satunya bersumber dari perilaku manusia membuang sampah. Secara sadar maupun tidak manusia telah lalai terhadap 
tanggung jawabnya kepada lingkungan hidup dan hanya mementingkan diri sendiri (Keraf, 2010).

Dalam proses pembelajaran, sumber belajar termasuk dalam sarana pembelajaran. Sumber belajar adalah segala sesuatu yang ada disekitar lingkungan kegiatan belajar yang secara fungsional dapat digunakan untuk membantu optimalisasi hasil belajar. Optimalisasi hasil belajar ini dapat dilihat tidak hanya dari hasil belajar (output), namun dilihat juga dari proses berupa interaksi siswa dengan berbagai macam sumber yang dapat merangsang untuk belajar dan mempercepat pemahaman dan penguasaan ilmu yang dipelajarinya (BSNP, 2006). Sumber dan media belajar mampu mendukung kegiatan belajar yang produktif, kreatif, inovatif, efektif dan efisien. Dengan adanya sumber dan media belajar yang mendukung tentu sangat berpengaruh terhadap motivasi belajar siswa yang lebih tinggi, sehingga mendapatkan hasil belajar yang maksimal dan mendapatkan pendidikan yang sesuai dengan tujuan pendidikan serta menjadi bangsa yang maju dibidangnya.

Untuk meningkatkan kualitas pendidikan yang sesuai dengan tujuan pendidikan itu sendiri, pendidikan harus disesuaikan dengan perkembangan zaman. Upaya yang dapat dilakukan diantaranya yakni melaksanakan pembelajaran sesuai dengan tujuan kurikulum yang produktif, kreatif, inovatif efektif dan efisien serta sumber dan media belajar yang tepat dalam mendukungnya suatu proses pembelajaran.

Krisis lingkungan menjadi arus utama perdebatan masyarakat dunia pada beberapa dasawarsa terakhir, setiap manusia yang peduli terhadap keberlangsungan kehidupan terus berusaha mencari alternatif-alternatif solusi, bagi krisis lingkungan dan bagaimana cara penanggulangannya sebagai isu bersama. 
Ecoliteracy sebagai sebuah paradigma baru yang dipopulerkan oleh Fritjof Capra (1995), bersama para praktisi lain baik dari praktisi pendidikan, praktisi lingkungan seperti David W Orr (1992), Michael $\mathrm{K}$ Stone and Zenobia Barlow (2005), menggagas gerakan dalam upaya kepedulian terhadap pengetahuan peduli terhadap lingkungan dan bertujuan meningkatkan kesadaran ekologis masyarakat. Ecoliteracy berupaya memperkenalkan dan memperbaharui pemahaman masyarakat akan pentingnya kesadaran ekologis global. Guna menciptakan keseimbangan antara kebutuhan masyarakat dan kesanggupan bumi untuk menopangnya.

Sumber belajar dan media pembelajaran yang sesuai dapat menciptakan suasana yang menyenangkan. Terkait permasalahan lingkungan, sumber belajar dan media belajar haruslah bersifat kontekstual dan dekat dengan keseharian siswa. Untuk itu perlu dikembangkannya sumber dan media belajar yang mengakomodir kebutuhan tersebut. Sumber dan media belajar yang sesuai dapat dimanfaatkan sedemikian rupa sehingga merangsang daya kreatif, berpikir kritis dan kerjasama. Utamanya pada pembelajaran IPS di sekolah, mengingat IPS adalah ilmu pengetahuan yang mengkaji berbagai disiplin ilmu sosial dan humoniora serta kegiatan dasar manusia yang di kemas secara ilmiah dalam rangka memberi wawasan dan pemahaman yang mendalam kepada peserta didik, khususnya di tingkat dasar dan menengah (Susanto, 2013).

Tujuan penelitian ini mengembangkan sumber dan media pembelajaran IPS dalam bentuk modul sebagai salah satu alternatif untuk meningkatkan kesadaran yang peduli terhadap lingkungan (ecoliteracy) peserta didik. Modul dipilih karena dapat membantu peserta didik untuk mencapai sejumlah tujuan belajar 
(Usman,2002). Modul yang dikembangakan peneliti secara umum berisi tentang kreasi-kreasi dari sampah botol plastik dan langkahlangkah pembuatannya. Mts Al-Hidayah merupakan sekolah yang dijadikan sebagai objek penelitian dalam implementasi produk modul yang dikembangkan oleh peneliti, modul daur ulang sampah botol plastik sebagai sumber dan media dalam pembelajaran IPS di kelas. Hal ini bertujuan untuk mengembagkan kemampuan peserta didik dari segi pengetahuan, sikap, maupun keterampilannya agar lebih peka dan peduli terhadap lingkungannya. Penelitian ini bermanfaat untuk peserta didik karena modul yang dikembangkan mengarahkan siswa menjadi aktif, senang dan tidak bosan karena seluruh alat indera terlibat dalam prosesnya, dengan pengalaman peserta didik mereka dapat lebih mengembangkan potensinya.

\section{Sumber dan Media Belajar}

Sumber belajar adalah semua sumber seperti pesan, orang, bahan, alat, teknik, dan latar yang dimanfaatkan peserta didik sebagai sumber untuk kegiatan belajar dan dapat meningkatkan kualitas belajarnya (Jonassen, 2015). Sumber belajar adalah segala daya yang dapat dimanfaatkan guna memberi kemudahan kepada seseorang dalam belajarnya (Nana, S \& Ahmad, 2013). Manfaat sumber belajar terhadap proses pembelajaran seperti: (1) Memungkinkan untuk menemukan bakat terpendam pada diri seseorang yang selama ini tidak tampak, (2) Memungkinkan pembelajaran berlangsung terus menerus dan belajar menjadi mudah diserap dan lebih siap diterapkan, dan (3) Seseorang dapat belajar sesuai dengan kecepatan waktu yang tersedia (Abdullah, 2012).

Media pembelajaran secara umum adalah alat bantu proses belajar mengajar. Segala sesuatu yang dapat dipergunakan untuk 
merangsang pikiran, perasaan, perhatian dan kemampuan atau keterampilanpembelajar sehingga dapat mendorong terjadinya proses belajar. Batasan ini cukup luas dan mendalam mencakup pengertian sumber, lingkungan, manusia dan metode yang dimanfaatkan untuk tujuan pembelajaran/ pelatihan. Media memiliki beberapa fungsi. Pertama, media pembelajaran dapat mengatasi keterbatasan pengalaman yang dimiliki oleh para peserta didik. Pengalaman tiap peserta didik berbeda-beda, tergantung dari faktor-faktor yang menentukan kekayaan pengalaman anak, seperti ketersediaan buku, kesempatan melancong, dan sebagainya. Media pembelajaran dapat mengatasi perbedaan tersebut. Jika peserta didik tidak mungkin dibawa ke obyek langsung yang dipelajari, maka obyeknyalah yang dibawa ke peserta didik. Obyek dimaksud bisa dalam bentuk nyata, miniatur, model, maupun bentuk gambar-gambar yang dapat disajikan secara audio visual.

Kedua, media dapat melampaui batasan ruang kelas. Banyak hal yang tidak mungkin dialami secara langsung di dalam kelas oleh para peserta didik tentang suatu obyek, yang disebabkan, karena: (a) obyek terlalu besar; (b) obyek terlalu kecil; (c) obyek yang bergerak terlalu lambat; (d) obyek yang bergerak terlalu cepat; (e) obyek yang terlalu kompleks; (f) obyek yang bunyinya terlalu halus; (f) obyek mengandung bahan berbahaya dan resiko tinggi. Melalui penggunaan media yang tepat, maka semua obyek itu dapat disajikan kepada peserta didik. Selain itu, media memungkinkan adanya interaksi langsung antara peserta didik dengan lingkungannya, menghasilkan keseragaman pengamatan, menanamkan konsep dasar yang benar, konkrit, dan realistis, membangkitkan keinginan dan minat baru, membangkitkan motivasi dan merangsang anak untuk belajar, dan memberikan 
pengalaman yang integral/menyeluruh dari yang konkrit sampai dengan abstrak.

Media pembelajaran lingkungan adalah pemahaman terhadap gejala atau tingkah laku tertentu dari objek atau pengamatan ilmiah terhadap sesuatu yang ada di sekitar sebagai bahan pengajaran peserta didik sebelum dan sesudah menerima materi dari sekolah dengan membawa pengalaman dan penemuan dengan apa yang mereka temui di lingkungan mereka dengan tujuan untuk mengupayakan agar terjadinya proses komunikasi atau interaksi antara siswa dan lingkungan atau masarakat (Sardiman, 2011).

Menggunakan apa yang ada di lingkungan sekitar sebagai media pembelajaran seperti lingkungan sosial, lingkungan alam, lingkungan buatan, ketiga jenis lingkungan ini akan sangat membantu dalam proses pembelajaran baik yang di tuangkan dalam audio visual maupun secara lansung yang nantinya peserta didik mampu mengobservasi sendiri apa yang di amatinya dan peserta didik memperoleh pengalaman lansung sebagai ilmu yang di aplikasikannya dari teori ke penerapan.

\section{Pembelajaran IPS}

Ilmu Pengetahuan Sosial (IPS) merupakan salah satu mata pelajaran yang mengkaji seperangkat peristiwa, fakta, konsep, dan generalisasi yang berkaitan dengan isu sosial. Pada jenjang SD/MI mata pelajaran IPS memuat materi Geografi, Sejarah, Sosiologi, dan Ekonomi. Melalui mata pelajaran IPS, peserta didik diarahkan agar menjadi warga negara Indonesia yang demokratis, dan bertanggung jawab, serta warga dunia yang cinta damai. Sejalan dengan tujuan pendidikan IPS. Tujuan pembelajaran IPS menurut (BSNP, 2006) yaitu: 1) mengajarkan konsep-kosep dasar sosiologi, geografi, ekonomi, sejarah, dan kewarganegaraan melalui pendekatan 
pendagogis dan psikologis; 2) mengembangkan kemampuan berpikir kritis dan kreatif, inkuiri, memecahkan masalah dan keterampilan sosial; 3) membangun komitmen dan kesadaran terhadap nilai-nilai sosial dan kemanusiaan; 4) meningkatkan kemampuan bekerjasama dan kompetensi dalam masyrakat yang majemuk, baik secara nasional maupun global.

Amanat kurikulum memang menuntut pembelajaran IPS sebagai pembelajaran yang memadukan sejumlah ilmu-ilmu sosial menjadi satu. Pemaduan ini menyisakan kekhawatiran dan pertanyaan besar. Pembelajaran IPS yang bersifat abstrak, sehingga ada kekhawatiran bila materi yang disampaikan di kelas hanya bersifat dangkal.

Kekhawatiran lain muncul karena dalam pembelajaran guru hanya mengandalkan buku guru dan buku siswa. Bahkan tidak jarang pembelajaran hanya berlangsung dengan guru bercerita saja. Akibatnya siswa memerlukan waktu yang lama untuk memahami materi-materi tersebut. Padahal idealnya, apapun permasalahan pembelajaran, utamanya kesulitan siswa dalam memahami materi dapat dibantu dengan sarana yang ada disekolah serta sumber belajar sebagai penunjang kegiatan belajar siswa.

Pembelajaran IPS juga idealnya bukanlah pembelajaran yang mengajarkan pengetahuan di tataran permukaan saja. Konsep pembelajaran tematik dalam pembelajaran IPS yang menghubungkan dengan pembelajaran lainnya tidak cukup hanya dengan lisan saja atau hanya mengandalkan buku guru dan buku siswa perlu adanya pemanfaatan sarana dan sumber belajar yang beragam. Konsep pembelajaran tematik justru harusnya dapat disajikan secara kontekstual berdasarkan permasalahan atau isuisu yang dekat dengan keseharian siswa. 


\section{Ecoliteracy}

Ecoliteracy atau sering disebut juga kecerdasan ekologi. Berasal dari kata Yunani oikos (habitat) dan logos (ilmu). Kecerdasan ekologi adalah kemampuan kita untuk beradaptasi terhadap ceruk ekologis tempat kita berada. Kecerdasan ekologis seseorang didasari atas pengetahuan, sikap/kesadaran, dan tindakan/perilaku hidup yang selaras dengan lingkungan alam. Seperti dijelaskan oleh Supritana (2016) bahwa kecerdasan ekologis bersifat kompleks. Kecerdasan tersebut didukung oleh unsur kognitif, afektif (sosial dan emosi), dan psikomotorik. Hasrat untuk menjaga lingkungan hidup didasari oleh pengetahuan tentang lingkungan. Kesadaran untuk menyelamatkan lingkungan yang rusak didasari oleh aspek afektif, sedangkan tindakan untuk menjaga kelestarian lingkungan menggambarkan aspek psikomotorik.

Keraf (2014) mengemukakan bahwa ecoliteracy berarti keadaan di mana seseorang, sudah tercerahkan tentang pentingnya lingkungan hidup. Ecoliteracy menggambarkan kesadaran tentang pentingnya lingkungan hidup. Dengan demikian, orang yang sudah sampai pada taraf ecoliteracy adalah orang yang sudah sangat menyadari betapa pentingnya lingkungan hidup, pentingnya menjaga dan merawat bumi, ekosistem, alam sebagai tempat tinggal dan berkembangnya kehidupan. Atas dasar dan digerakkan oleh kesadaran inilah manusia menata pola dan gaya hidupnya menjadi pola dan gaya hidup yang selaras dengan lingkungan hidup. Manusia lalu menggunakan kesadaran tersebut untuk menuntun hidupnya dalam segala dimensinya sampai menjadi sebuah budaya yang merasuki semua anggota masyarakat untuk akhirnya terciptalah sebuah masyarakat yang berkelanjutan. 
Ecoliteracy merupakan cara berpikir tentang dunia dalam hal sistem alam dan manusia yang saling bergantung termasuk pertimbangan dari konsekuensi dari tindakan manusia dan interaksi dalam konteks alami. Melek ekologi melengkapi siswa dengan pengetahuan dan kompetensi yang diperlukan untuk menangani masalah lingkungan yang kompleks dan mendesak secara terpadu dan memungkinkan mereka untuk membantu membentuk masyarakat yang berkelanjutan dengan tidak merusak ekosistem.

Penelitian ini merujuk pada implementasi kompetensi ecoliteracy yang dikembangkan oleh the Centre for Ecoliteracy yang telah mengembangkan seperangkat "kompetensi inti" untuk membantu siswa dalam mengembangkan kemampuan sikap, pengetahuan dan keterampilan ecoliteracy dalam upaya mendukung suistainable development. Kompetensi inti tersebut mencakup aspek head (cognitive) competencies atau learning to know, heart (emotional) competencies atau learning to be, hands (active) competencies atau learning to do, dan spirit competencies atau learning to live together, The Centre for Ecoliteracy (2011).

Peningkatan sikap peduli lingkungan siswa merupakan hal yang sangat penting untuk dikembangkan sejak dini. Siswa dikatakan telah memiliki sikap apabila telah melakukan tindakan yang sama pada situasi yang sama. Hal tersebut terjadi secara berulang-ulang. Pembiasaan nilai-nilai karakter sikap positif tidak akan mudah luntur sehingga seiring dengan perkembangan usia, siswa akan menjadi terbiasa untuk senantiasa peduli terhadap lingkungan di sekitarnya baik di lingkungan sekolah, rumah, maupun lingkungan masyarakat. 
Permasalahan lingkungan yang terjadi pada saat ini, seperti banyaknya sampah merupakan suatu permasalahan yang diakibatkan oleh ulah manusia yang mencerminkan ketidakpeduliannya terhadap lingkungan. Mereka tidak memiliki aturan hidup dan nilai-nilai terhadap lingkungan. Beberapa permasalahan lingkungan yang terjadi menggambarkan kesadaran pentingnya lingkungan hidup yang masih kurang. Kesadaran inilah yang disebut Capra (2002) sebagai ecoliteracy.

Untuk menumbuhkan ecoliteracy siswa haruslah ada sebuah penelitian yang bertujuan untuk meningkatkan ecoliteracy yang nantinya tumbuh dan berkembang menjadi sebuah kesadaran dari setiap individu. Hal tersebut akan sangat dirasa penting seiring dengan berkembangnya ilmu pengetahuan dan teknologi. Tanpa kesadaran lingkungan, maka ilmu pengetahuan dan teknologi tersebut akan justru berpengaruh pada ketidakseimbangan alam. Dengan demikian, harus ada tindakan-tindakan nyata untuk mengembangkan ecoliteracy siswa. Berangkat dari hal yang kecil di sekolah, guru dapat mengajarkan dan menumbuhkan pemahaman akan lingkungan ini melalui pembelajaran.

Peningkatan ecoliteracy dengan cara pengelolaan sampah yang dilakukan secara langsung oleh setiap siswa merupakan bentuk kepedulian terhadap lingkungan sekitar sekaligus dapat meningkatkan kepedulian sosial yang berpengaruh terhadap pembentukan karakter. Guru berperan untuk meningkatkan ecoliteracy siswa dalam pembelajaran IPS. Peranan yang diemban seorang guru bukan perkara mudah dalam hal menjalankannya. Seperti yang diketahui kebanyakan guru hanya mengetahui kemampuan kognitif siswa yang memungkinkan untuk berkembang. Disinilah tuntutan untuk bisa melihat dan membuka 
mata sebagai seorang guru untuk berusaha keras memberikan yang terbaik bagi perkembangan setiap siswanya. Perkembangan tersebut bukan hanya kognitifnya saja, tetapi aspek sikap dan keterampilannyapun harus dikembangkan. Dengan kata lain, guru mempunyai peranan penting dalam mengembangkan potensi yang dimiliki oleh setiap siswa.

Dengan tuntutan seperti itu guru pasti bisa mengembangkannya asalkan ada kesungguhan untuk memperbaiki keadaan yang awalnya kurang maksimal menjadi lebih baik. Proses pembelajaran yang kurang maksimal yang dilakukan oleh guru mencerminkan kompetensi yang masih harus terus diperbaiki. Oleh karena itu, guru harus bercermin kepada siswanya agar memiliki gambaran mengenai hal yang menjadi kebutuhan setiap siswa dalam setiap proses pembelajaran yang dilakukan supaya dapat memfasilitasi kebutuhan setiap siswanya.

\section{METODE}

\section{Model Pengembangan}

Dalam penelitian ini menggunakan penelitian jenis pengembangan atau Research and Development (R\&D). Metode penelitian R\&D (Sugiyono, 2011) adalah suatu metode penelitian yang digunakan untuk menghasilkan produk dan keefektifan dari produk tersebut akan diuji. Penelitian R\&D dalam pendidikan merupakan proses yang digunakan untuk mengembangkan dan mengetahui validitas suatu produk. Jadi, penelitian pengembangan yang akan dilakukan peneliti adalah mendesain produk berupa modul sebagai sumber belajar IPS, kemudian melakukan validasi terhadap produk modul tersebut.

Validasi produk akan dilakukan oleh ahli materi, yang pada penelitian ini adalah guru IPS, dan ahli media. Sumber dan media 
pembelajaran kemudian diujicobakan kepada peserta didik MTs AlHidayah dalam pembelajaran IPS di kelas. Melalui tahapan ini dapat diketahui kelayakan dari produk modul untuk dijadikan sebagai sumber belajar IPS.

\section{Prosedur Penelitian}

Ada sepuluh langkah pelaksanaan strategi penelitian yang telah dipilih dalam penelitian ini, yaitu strategi Borg dan Gall dalam Sukmadinata (2009):

1) penelitian dan pengumpulan data (research and information collecting). Pengukuran atas suatu studi literatur, kebutuhan, penelitian skala kecil dan sebuah pertimbangan tergtentu dari segi nilai;

2) perencanaan (planning). Perencanaan penelitian, meliputi kemampuan yang diperlukan ketika melaksanaan penelitian tersebut, rumusan atas tujuan yang ingin dicapai dengan penelitian, langkah-langkah suatu penelitian, dan kemungkinan pengujian dalam lingkup yang terbatas;

3) pengembangan draf produk (develop preliminary from of product). Mengembangkan sebuah bahan pembelajaran, proses dalam pembelajaran dan instrumen evaluasinya;

4) uji coba lapangan awal (preliminary field testing). Uji coba maksudnya dengan melakukan pengamatan, wawancara dan angket yang disebarkan;

5) melakukan revisi atas hasil uji coba (main product revision). Memperbaiki atau menyempurnakan hasil uji coba;

6) uji coba lapangan (main filed testing). Uji coba yang dilakukan di lapangan;

7) penyempurnaan produk hasil uji lapangan (operational 
product revision). Menyempurnakan produk dari hasil yang telah diujikan di lapangan;

8) uji pelaksanaan lapangan (operational field testing). Pengujian ini dilakukan dengan observasi, wawancara, angket dan analisi hasil;

9) penyempurnaan produk akhir (final product revision). Menyempurnakan produk atas dasar masukan dari uji pelaksanaan di lapangan; dan

10) diseminasi dan implementasi (dissemination and implementation). Melaporkan hasilnya dalam pertemuan dengan profesional dan ke dalam jurnal.

Peneliti menyederhanakan tahapan dari kesepuluh tahapan tersebut yang di dasari oleh pendapat Borg dan Gall dalam Emzir (2011) yang menyarankan adanya pembatasan penelitian skala kecil, termasuk kemungkinan untuk pembatasan langkahlangkah penelitian. Karena keterbatasan waktu sehingga tahapan penelitian dibatasi dan disederhanakan. Tahapan ini dipadukan dengan tahapan pembuatan modul dalam dua tahap. Pertama, tahap penelitian dan pengumpulan data, meliputi penentuan gagasan dan tujuan pembuatan produk yaitu menetapkan modul sebagai sumber belajar dengan materi kewirausahaan, dan pengumpulan materi mengenai Kewirausahaan pada kurikulum 2013 yang berasal dari buku paket mata pelajaran IPS kelas VII dan ebook tentang materi kewirausahaan untuk mata pelajaran IPS kelas VII.

Kedua, tahap perencanaan yang meliputi pembuatan ide modul yang sesuai dengan materi kewirausahaan. Ide berawal dari banyaknya sampah produk kemasan konsumsi berupa makanan dan minuman dalam beberapa bentuk seperti kertas, plastik, kaleng dan styrofoam. Pada penelitian ini akan difokuskan kepada 
sampah kemasan produk konsumsi berupa botol plastik. Pembuatan modul didasarkan pada kreatifitas mendaur ulang sampah kemasan produk konsumsi berupa botol plastik menjadi produk baru. Hal ini juga sejalan dengan contoh yang ada di buku paket siswa mengenai daur ulang sampah.

Ketiga, tahap pengembangan produk. Kegiatan ini meliputi pembuatan modul dengan mengumpulkan materi-materi bersumber pada referensi internet tentang kreatifitas mendaur ulang sampah kemasan produk konsumsi berupa botol plastik menjadi barang yang masih bisa digunakan kembali dalam bentuk produk baru bahkan bernilai jual.

Materi-materi tersebut kemudian ditata ulang menjadi sebuah modul yang berisi tentang gambar contoh produk baru hasil daur ulang sampah kemasan botol plastik. Dalam pembuatan produk peneliti mempertimbangkan kesederhanaan dalam pembuatannya sehingga dapat dengan mudah dilakukan oleh peserta didik, namun tidak akan membatasi kreatifitas peserta didik jika ingin mengembangkan produk menjadi lebih unik. Pemberian keterangan tata cata pembuatan atau tutorial membuat produk tersebut yang bisa dibaca sehingga bisa dipraktekkan dengan mudah oleh peserta didik.

Keempat, tahapan validasi dan uji coba, yaitu: a) tahap validasi dilakukan oleh ahli materi dan ahli media; b) revisi tahap I; c) tahap validasi dilakukan oleh guru IPS MTs Al-Hidayah Wajak; d) revisi tahap II; e) uji coba produk pada peserta didik kelas VII MTs Al-Hidayah Wajak; f) penyempurnaan produk akhir. 


\section{Uji Coba Produk}

Peneliti melakukan desain untuk uji coba agar mengetahui seberapa kualitas dari produk yang dikembangkan oleh peneliti. Kelayakan dari produk diujikan untuk kemudian dijadikan sebagai sumber belajar peserta didik. Penilaian produk dilakukan oleh ahli materi dan ahli media, selanjutnya dilakukan revisi tahap I dan produk dinilai kembali oleh guru IPS, kemudian dilakukan revisi tahap II. Setelah itu, produk diujicobakan kepada pesera didik kelas VII MTs Al-Hidayah Wajak sebelum produk akan menjadi produk akhir yang layak dan berkualitas sebagai sumber belajar IPS.

Validator pada penelitian ini adalah ahli materi IPS, ahli media pembelajaran, dan guru IPS. Subjek uji coba pada penelitian ini adalah 80 siswa kelas VII MTs Al-Hidayah Wajak. MTs AlHidayah Wajak dijadikan tempat uji coba penelitian karena belum banyak terdapat pengembangan sumber belajar berupa modul.

\section{HASIL DAN PEMBAHASAN}

\section{Hasil}

Penelitian ini memiliki dua tujuan, yang pertama pengembangkan modul sebagai sumber dan media pembelajaran agar peserta didik memiliki kemampuan pengetahuan, keterampulan dan sikap ecoliteracy dan green consumer dan yang kedua adalah mengimplementasikan modul yang sudah dikembangkan dalam proses pembelajaran mata pelajaran IPS.

Peneliti menyusun instrumen agar mengetahui kualitas dari sumber belajar yang telah dikembangkan. Instrumen pada penelitian ini adalah lembar penilaian mengenai kelayakan modul. Penilaian dilakukan oleh ahli materi, ahli media, guru IPS, dan tanggapan oleh siswa SMP Kelas VII. Kisi-kisi instrumen penilaian disajikan pada tabel berikut: 
Tabel 1. Kisi-kisi Instrumen Penilaian dari Pengembangan Modul sebagai Sumber dan Media Pembelajaran IPS untuk Ahli Materi

\begin{tabular}{|c|c|c|c|c|}
\hline No. & $\begin{array}{l}\text { Aspek } \\
\text { yang } \\
\text { Dinilai }\end{array}$ & Indikator & $\begin{array}{c}\text { Butir } \\
\text { Instrumen }\end{array}$ & $\begin{array}{c}\text { Jumlah } \\
\text { Butir }\end{array}$ \\
\hline \multirow{5}{*}{1.} & \multirow{5}{*}{ Kelayakan Isi } & Kelengkapan materi & 1,2 & 2 \\
\hline & & Keluasan materi & 3,4 & 2 \\
\hline & & Kedalaman materi & 5 & 1 \\
\hline & & Keakuratan materi & 6 & 1 \\
\hline & & $\begin{array}{l}\text { Materi pendukung } \\
\text { Pembelajaran }\end{array}$ & $7,8,9,10$ & 4 \\
\hline 2. & $\begin{array}{l}\text { Kelayakan } \\
\text { Penyajian }\end{array}$ & Penyajian pembelajaran & 11,12 & 2 \\
\hline 3. & $\begin{array}{l}\text { Kelayakan } \\
\text { Bahasa }\end{array}$ & $\begin{array}{l}\text { Kesesuaian dengan } \\
\text { tingkat perkembangan } \\
\text { peserta didik }\end{array}$ & 13,14 & 2 \\
\hline
\end{tabular}

Tabel 2. Kisi-kisi Instrumen Penilaian dari Pengembangan Modul sebagai Sumber dan Media Pembelajaran IPS untuk Ahli Media

\begin{tabular}{|c|c|c|c|c|}
\hline No. & $\begin{array}{l}\text { Aspek } \\
\text { yang } \\
\text { Dinilai }\end{array}$ & Indikator & $\begin{array}{l}\text { Butir } \\
\text { Instrumen }\end{array}$ & $\begin{array}{c}\text { Jumlah } \\
\text { Butir }\end{array}$ \\
\hline \multirow{3}{*}{1.} & \multirow{3}{*}{$\begin{array}{l}\text { Kelayakan } \\
\text { Isi }\end{array}$} & Kelengkapan materi & 1,2 & 2 \\
\hline & & Keluasan materi & 3 & 1 \\
\hline & & $\begin{array}{l}\text { Materi pendukung } \\
\text { Pembelajaran }\end{array}$ & $4,5,6$ & 3 \\
\hline \multirow{3}{*}{2.} & \multirow{3}{*}{$\begin{array}{l}\text { Kelayak } \\
\text { an } \\
\text { Penyaji } \\
\text { an }\end{array}$} & Teknik penyajian & 7,8 & 2 \\
\hline & & Penyajian pembelajaran & 9,10 & 2 \\
\hline & & Kelengkapan penyajian & 11,12 & 2 \\
\hline \multirow[t]{4}{*}{3.} & \multirow{4}{*}{$\begin{array}{l}\text { Kelayak } \\
\text { an } \\
\text { Bahas } \\
\text { a }\end{array}$} & $\begin{array}{l}\text { Kesesuaian dengan } \\
\text { tingkat perkembangan } \\
\text { peserta didik }\end{array}$ & 13,14 & 2 \\
\hline & & Kekomunikafifan & 15,16 & 2 \\
\hline & & $\begin{array}{l}\text { Keruntutan dan } \\
\text { keterpaduan alur pikir }\end{array}$ & 17 & 1 \\
\hline & & Ukuran buku & 18 & 1 \\
\hline
\end{tabular}




\begin{tabular}{|c|c|c|c|c|}
\hline \multirow[t]{2}{*}{4.} & \multirow{2}{*}{$\begin{array}{l}\text { Kelayak } \\
\text { an } \\
\text { Kegrafik } \\
\text { an }\end{array}$} & Desain sampul buku & $\begin{array}{l}19,20,21, \\
22,23,24\end{array}$ & 6 \\
\hline & & Desain isi buku & $\begin{array}{c}25,26,27, \\
28,29,30, \\
31,32,33\end{array}$ & 9 \\
\hline
\end{tabular}

Tabel 3. Kisi-kisi Instrumen Penilaian Pengembangan Modul sebagai Sumber dan Media Pembelajaran IPS untuk Guru IPS

\begin{tabular}{|c|c|c|c|c|}
\hline No. & $\begin{array}{l}\text { Aspek } \\
\text { yang } \\
\text { Dinilai }\end{array}$ & Indikator & $\begin{array}{l}\text { Butir } \\
\text { Instrumen }\end{array}$ & $\begin{array}{c}\text { Jumlah } \\
\text { Butir }\end{array}$ \\
\hline \multirow{5}{*}{1.} & \multirow{5}{*}{ Kelayakan Isi } & Kelengkapan materi & 1,2 & 2 \\
\hline & & Keluasan materi & 3,4 & 2 \\
\hline & & Kedalaman materi & 5 & 1 \\
\hline & & Keakuratan materi & 6 & 1 \\
\hline & & $\begin{array}{l}\text { Materi pendukung } \\
\text { Pembelajaran }\end{array}$ & $7,8,9,10$ & 4 \\
\hline 2 . & $\begin{array}{c}\text { Kelayakan } \\
\text { Penyajian }\end{array}$ & Penyajian pembelajaran & 11,12 & 2 \\
\hline \multirow[t]{3}{*}{3.} & \multirow{3}{*}{$\begin{array}{l}\text { Kelayaka } \\
\mathrm{n} \\
\text { Bahasa }\end{array}$} & $\begin{array}{l}\text { Kesesuaian dengan } \\
\text { tingkat perkembangan } \\
\text { peserta didik }\end{array}$ & 13,14 & 2 \\
\hline & & Kekomunikatifan & 15 & 1 \\
\hline & & $\begin{array}{l}\text { Keruntutan dan } \\
\text { keterpaduan alur pikir }\end{array}$ & 16 & 1 \\
\hline 4. & $\begin{array}{l}\text { Kelayakan } \\
\text { Kegrafikan }\end{array}$ & Desain isi & 17,18 & 2 \\
\hline
\end{tabular}

Tabel 4. Kisi-kisi Instrumen Tanggapan Siswa terhadap Pengembangan Modul sebagai Sumber dan Media Pelajaran IPS

\begin{tabular}{|c|l|l|c|c|}
\hline No. & \multicolumn{1}{|c|}{$\begin{array}{c}\text { Aspek } \\
\text { yang } \\
\text { Dinilai }\end{array}$} & \multicolumn{1}{|c|}{ Indikator } & $\begin{array}{c}\text { Butir } \\
\text { Instrume } \\
\mathrm{n}\end{array}$ & $\begin{array}{c}\text { Jumlah } \\
\text { Butir }\end{array}$ \\
\hline 1. & Kelayakan Isi & $\begin{array}{l}\text { Materi pendukung } \\
\text { Pembelajaran }\end{array}$ & 1,2 & 2 \\
\hline 2. & $\begin{array}{l}\text { Kelayakan } \\
\text { Penyajian }\end{array}$ & $\begin{array}{l}\text { Penyajian } \\
\text { Pembelajaran }\end{array}$ & 3,4 & 2 \\
\hline
\end{tabular}




\begin{tabular}{|c|l|l|c|c|}
\hline 3. & $\begin{array}{l}\text { Kelayakan } \\
\text { Bahasa }\end{array}$ & $\begin{array}{l}\text { Kesesuaian dengan } \\
\text { tingkat perkembangan } \\
\text { peserta didik }\end{array}$ & 5,6 & 2 \\
\cline { 2 - 5 } Kekomunikatifan & 7,8 & 2 \\
\hline 4. & $\begin{array}{l}\text { Kelayakan } \\
\text { Kegrafikan }\end{array}$ & Desain isi & 9,10 & 2 \\
\hline
\end{tabular}

Analisis yang digunakan dalam penelitian ini adalah analisis deskriptif sesuai dengan prosedur pengembangan yang telah dilakukan oleh peneliti. Modul yang di kembangkan adalah mata pelajaran IPS dengan materi kewirausahaan. Pada tahap awal dalam pengembangan melakukan pengumpulan referensi atau bahan materi kewirausahaan. Tahap selanjutnya merupakan tahap membuat produk awal berupa modul dan penyusunan instrumen dari penilaian modul. Tahap terakhir ini yaitu penilaian dari modul oleh ahli. Produk awal berupa modul ini divalidasi oleh ahli materi IPS dan ahli media kemudian diperoleh hasil revisi pengembangan dari tahap I. Kemudian tahapan berikutnya adalag penilaian yang dilakukan oleh guru mata pelajaran IPS yang selanjutnya akan dihasilkan revisi produk pada tahap II.

Tahapan berikutnya berupa uji coba kepada 80 siswa kelas VII MTs Al-Hidayah Wajak yang selanjutnya akan diperoleh revisi untuk dijadikan penyempurnaan dari produk akhir. Dari tahap-tahap revisi dalam produk tersebut, maka akan menghasilkan produk akhir modul sebagai sumber dan media pembelajaran IPS dengan materi Kewirausahaan untuk diterapkan peserta didik Kelas VII di MTs Al-Hidayah Wajak.

Langkah-langkah dari analisis data atas kelayakan modul dengan mengubah suatu penilaian data yang berbentuk kualitatif dijadikan data yang berbentuk kuantitatif dengan ketentuan sebagai berikut: 
Tabel 5. Pedoman Penilaian Skor

\begin{tabular}{|l|l|}
\hline \multicolumn{1}{|c|}{ Data Kualitatif } & Skor \\
\hline SB (Sangat Baik) & \\
\hline B (Baik) & \\
\hline C (Cukup) & \\
\hline K (Kurang) & \\
\hline SK (Sangat Kurang) & \\
\hline
\end{tabular}

Sumber: Saifuddin Azwar, 2007: 163

\section{Pembahasan}

\section{Ecoliteracy dalam Pembelajaran IPS}

Ecoliteracy merupakan gambaran dari kesadaran seorang individu terhadap lingkungannya yang dianggap sesuatu yang sangat penting. Orang yang menyadari akan pentingnya menjaga lingkungan dianggap sudah masuk pada level ekoliterasi. Mereka tidak akan semena-mena terhadap lingkungan dan ekosistem yang ada disekitarnya, bahkan mereka akan senantiasa menjaga dan merawat alam yang merupakan tempat bagi makhluk hidup. Tidak bisa di sangkal berbagai kasus lingkungan hidup yang terjadi sekarang, baik yang disebabkan oleh sampah maupun faktor lainnya, sebagian besar bersumber dari manusianya.

Secara sadar atau tidak sadar manusia telah lalai terhadap tanggung jawabnya kepada lingkungan hidup dan hanya mementingkan diri sendiri (Keraf, 2010). Orang yang sudah sampai pada level ecoliteracy akan berpikir bahwasanya manusia dan alam saling ketergantungan satu sama lain, sehingga akan selalu ada interaksi yang terjadi alami antar manusia dengan alam. Kemampuan ekologi membantu peserta didik memahami mengenai bagaimana mengatasi masalah yang terjadi pada lingkungan sekitarnya dan pengetahuan bagaimana seharusnya sikap peserta didik terhadap lingkungannya. 
Perilaku kepedulian terhadap lingkungan yang dilakukan individu bisa dengan cara menerapkan dalam kehidupan seharihari untuk lebih memilih menggunakan produk yang ramah lingkungan sehingga tidak merusak ekosistem yang ada. Dalam usia seorang anak yang masih duduk di bangku Sekolah Menengah Pertama perlulah dilatih perilaku tersebut, tidak serta merta peserta didik memiliki kesadraan ekoliterasi karena tidak semua peserta didik dilatih untuk mencintai lingkungan oleh keluarga maupun pada sekolah tingkat dasar.

Disini tugas guru IPS di Sekolah Menengah Pertama (SMP) sebagai pembimbing yang mengajarkan, mengarahkan dan memberi contoh agar peserta didik memiliki kecerdasan ekologi supaya mereka lebih peduli terhadap lingkungan. Peserta didik sebagai konsumen akan lebih memilih membeli produk dengan lebih hati-hati dan mempertimbangankan bagaimana dampaknya terhadap lingkungan.

Alternatif lain media pembelajaran IPS juga bisa memanfaatkan beberapa sumber dan media pembelajaran yang bisa diperoleh dari lingkungan, termasuk sampah. Sampah yang bisa dimanfaatkan salah satunya sampah botol plastik yang kebanyakan merupakan kemasan minuman. Dari sampah tersebut bisa dijadikan menjadi produk baru yang bermanfaat bahkan bisa juga memiliki nilai ekonomi. Caranya dengan mendaur ulang sampah botol plastik bekas kemasan minum tersebut. Daur ulang ini merupakan pembelajaran sederhana yang tidak menyulitkan sehingga bisa dipraktekkan oleh peserta didik dengan bahan dan alat yang sangat mudah didapatkan.

Daur ulang yang bisa dipraktekkan oleh peserta didik dalam pembelajaran IPS di kelas lebih dimudahkan dengan beberapa 
contoh dan tata cara pembuatan produk daur ulang yang tersusun dalam sebuah modul pembelajaran. Modul tersebut menjadi contoh yang menggugah kretifitas peserta didik. Peserta didik tidak harus terpaku atau mengikuti persis seperti contoh dalam modul, melainkan bisa mengembangkan dari contoh dalam modul atau bisa pula membuat produk baru yang tidak tercantum dalam modul. Dengan praktek daur ulang tersebut peserta didik bisa tersaluran kreatifitasnya.

Produk-produk yang dihasilkanpun sangatlah beragam mulai dari produk-produk sederhana seperti botol plastik yang didaur ulang menjadi wadah pensil, pot bunga atau laiinya. Adapula produk daur ulang yang lebih rumit, misakkan membuat hiasan dari rangkaian botol kekas yang telah dibentuk sesuai kreatifitas peserta didik. Tidak hanya itu, ada pula sekelompok peserta didik yang berhasil menjual kreasi daur ulangnya sehingga mereka bersemangat untuk membuat kreasi produk daur ulang lainnya dari kemasan botol plastik dan menjuanya melalui media social, seperti facebook, intagram atau lainnya. Sehingga banyak aspek yang diperoleh dalam pembelajaran ini, mulai dari aspek geografi, ekonomi, seni dan lainnya. Praktek daur ulang kemasan botol plastik ini menjadi kegiatan yang sangat menyenangkan dalam pelaksanaan pembelajaran IPS. Bahan dan alatnyapun sangat mudah didapatkan serta tidak memerlukan sarana prasana yang tertentu.

Penelitian yang telah dilakukan ini merupakan sebuah penelitian penerapan dari pengetahuan ecoliteracy yang telah diajaran baik oleh guru maupun sekolah kepada peserta didik agar mereka bisa bersikap yang tepat terhadap lingkungan demi menjaga keseimbangan ekosistem yang telah berjalan dengan baik. 
Penelitian pengembangan yang telah dilakukan peneliti adalah mendesain produk berupa modul sebagai sumber belajar IPS kemudian melakukan validasi terhadap produk modul tersebut. Validasi produk ini dilakukan oleh ahli media, ahli mater, dan guru IPS kemudian diujicobakan kepada siswa MTs Al-Hidayah sampai dinyatakan layak dan produk modul untuk dijadikan sebagai sumber belajar IPS dan siap untuk diseminasi.

Adapun isi modul terdiri dari tiga bagian yang pertama adalah Pendahuluan, Kreasi Daur Ulang Botol Plastik dan Berwirausaha. Pendahuluan berisi tentang masalah masalah atau dampakdampak dari sampah botol plastik dan solusi permasalahan tersebut, Adapun bagian kreasi daur ulang berisi tentang macam kreasi-kreasi inovatif dari sampah botol plastik yang terdiri dari 21 macam kreasi beserta langkah-langkah dalam membuatnya. Bagian terahir yaitu tentang berwirausaha yang menceritakan tentang kisah-kisah inspiratif dari pengusaha sampah botol plastik. Modul daur ulang sampah botol plastik dapat mengembangkan ecoliteracy peserta didik karena modul merupakan media dan sumber belajar yang dapat menjadkan peserta didik tidak membosankan selama pelakanaan pembelajaran, lebih menyanangkan dan menggugah peserta didik untuk lebih aktif.

\section{KESIMPULAN}

Berdasarkan permasalahan yang ada terkait dengan banyaknya limbah sampah yang dapat merusak lingkungan hidup, maka peneliti mengembangkan sebuah produk berupa berupa modul sumber dan media pembelajaran IPS dengan judul "Kreasi Unik Daur Ulang Kemasan Botol Plastik" yang mengadopsi dari materi Kewirausahaan. Penelitian ini diharapkan kedepannya dapat meningkatkan ecoliteracy peserta didik sebagai green consumer. 
Modul ini telah di desiminasi di sekolah tingkat SMP dan dapat digunakan dalam proses pelaksanaan pembelajaran di kelas pada mata pelajaran IPS yang dengan pengamalannya dapat mengembangkan kemampuan intelektual dan kreatifitas dari peserta didik untuk meningkatkan ecoliteracy. Modul ini sangat membantu peserta didik untuk aktif, senang dan tidak bosan dalam pembelajaran khususnya pembelajaran IPS, peserta didik juga bisa peduli dengan lingkungannya, peserta didik juga dapat mengembangkan potensinya untuk berkreasi dalam mengembangkan jiwa kewirausahaannya khususnya berkreasi dari bahan sampah botol plastik yang dapat memiliki nilai ekonomi.

\section{DAFTAR PUSTAKA}

Abdullah, R. (2012). Pemanfaatan Berbasis Pemanfaatan Sumber Belajar, 12(2), 216-231. http:/ /dx.doi.org/ 10.22373/jid.v12i2.449

Akhdi, Mukhlis. (2014). Isu Lingkungan Hidup. Yogyakarta: Graha Ilmu

Asdak, Chay. (2014). Kajian Lingkungan Hidup Strategis. Yogyakarta: Gajah Mada University Press.

Azwar, Saifuddin. (2007). Metode Penelitian. Yogyakarta: Pustaka Pelajar.

BSNP. (2006). Panduan Penyusunan Kurikulum Tingkat Satuan Pendidikan Jenjang Pendidikan Dasar dan Menengah. Jakarta: Depdiknas.

Emzir. (2011). Metodologi Penelitian Kualitatif Analisis Data. Jakarta: Rajawali Press.

Huriah, R. (2014). Pengembangan Profesi Pendidikan IPS. Bandung: Alfabeta. Capra, F (2002). Jaring-jaring Kehidupan. Yogyakarta. Fajar Pustaka Baru. 
Iskandar, Johan. (2014). Manusia dan Lingkungan dengan berbagai Perubahannya. Yogyakarta: Graha Ilmu.

Jonassen, D. (2015). Pemanfaatan Sumber Belajar Dalam Proses Pembelajaran. Fakultas Tarbiyah dan Keguruan UIN ArRaniry Banda Aceh, 3(2).

Keraf, A Sony. (2010). Etika Lingkungan Hidup. Yogyakarta: Kanisius.

Keraf, Sonny A. (2014). Filsafat Lingkungan Hidup, Alam sebagai Sebuah Sistem Kehidupan (bersama Fritjop Capra). Yogyakarta: Kanisius.

Nana, S \& Ahmad, R. (2013). Teknologi Pengajaran. Bandung: Sinar Baru Algensindo.

Purwanto, M. Ngalim. (2002). Prinsip-prinsip dan Teknik Evaluasi Pengajaran. Bandung: PT Remaja Rosdakarya.

Rayandra, A. (2011). Kreatif Mengembangkan Media Pembelajaran. Jakarta: Gaung Persada.

Republika. (2019). Sampah Indonesia Terus Meningkat Tiga Juta Tahun.

https://nasional.republika.co.id/berita/pus5ex368/sam pah-indonesia-terus-meningkat-tiga-juta-ton-tiap-tahun

Santoso, Minto. (2015). Korelasi Penggunaan Media, Disiplin Belajar dan Motivasi Belajar terhadap Prestasi Belajar IPS. Cendekia, 9(2): 149-158.

Sardiman, Arif. 2011. Media Pendidikan. Rajawali Pers. Jakarta.

Sugiono. (2011). Metode Penelitian Kuantitatif, kulitatif dan R\&D. Bandung: Alfabeta.

Sugiono. (2014). Metode Penelitian Kuantitatif, Kualitatif dan R\&D. Bandung: Alfabeta.

Sukmadinata, Nana Syaodih. (2009). Metode Penelitian Pendidikan. Bandung: Remaja Rosdakarya.

Soemarwoto, Otto. (1992). Analisis Dampak Lingkungan. Yogyakarta: Gajah Mada University Press.

Soemarwoto, Otto. (2009). Atur Diri Sendiri: Paradigma Baru Pengelolaan Lingkungan Hidup. Yogyakarta: Gajah Mada University Press. 
Trianto. 2012. Model Pembelajaran Terpadu. Bumi Aksara. Jakarta.

Usman Basyiruddin. (2002). Metodologi Pembelajaran Agama Islam. Jakarta: Ciputat Pers.

Wiryono. (2013). Pengantar Ilmu Lingkungan. Bengkulu: Pertelon Media. 